DOI: $10.17951 / \operatorname{lrp} .2019 .38 .2 .27-40$

\title{
Matgorzata OsıŃsKa
}

Uniwersytet Marii Skłodowskiej Curie

Wydział Pedagogiki i Psychologii

ORCID: 0000-0002-0609-2327

\section{DIAGNOZA RESOCJALIZACYJNA W PRAKTYCE KURATORÓW SĄDOWYCH}

\begin{abstract}
Streszczenie: Diagnoza resocjalizacyjna jest nieodłącznym elementem praktyki kuratorskiej, ściśle związanym z efektywnością podejmowanych oddziaływań. Proces diagnostyczny wymaga rozpoznania przyczyn, stopnia i dynamiki nieprzystosowania społecznego oraz wskazania zarówno zasobów sprzyjających powtórnej socjalizacji, jak i czynników ryzyka, mogących przyczynić się do zniweczenia całego procesu zmian. Konsekwencją diagnozy powinno być ustalenie możliwych kierunków pracy z jednostką nieprzystosowaną, prognoza jej funkcjonowania w przyszłości oraz sformułowanie adekwatnego planu pracy resocjalizacyjnej.

Celem niniejszego opracowania jest zwrócenie uwagi na szereg trudności, z jakimi borykają się kuratorzy sądowi na etapie tworzenia diagnozy, jej weryfikacji i ewaluacji. Są to przykładowo trudności natury etycznej, ale też wynikające z braku narzędzi diagnostycznych i ograniczeń czasowych, spowodowanych znaczną liczbą innych absorbujących obowiązków. Analiza wskazanej problematyki skłoniła do wniosku, iż zasadnym jest postulat systematycznego pogłębiania wiedzy z zakresu teoretycznych założeń i praktycznych umiejętności diagnozowania oraz wykorzystania uzyskanych wniosków w pracy z podopiecznym.
\end{abstract}

Słowa kluczowe: diagnoza resocjalizacyjna, kurator sądowy, proces resocjalizacji

\section{WPROWADZENIE}

Jednym z podstawowych obowiązków kuratorów sądowych, w ramach prowadzonych postępowań, jest przygotowanie diagnozy. Odbywa się to bądź na bezpośrednie zlecenie sądu, bądź wynika z potrzeby rozpoznania sytuacji na potrzeby własnej pracy z podopiecznymi i ich rodzinami. Proces diagnozowania wiąże się z koniecznością pozyskania, a następnie analizy informacji o osobie, której do- 
tyczy postępowanie, w tym o jej środowisku życia, funkcjonowaniu społecznym, przejawach niedostosowania i ich nasileniu oraz, co istotne z praktycznego punktu widzenia, możliwościach wprowadzenia zmian (Jedynak 2014).

Zagadnienia dotyczące diagnozy budzą w środowisku kuratorów wiele pytań odnoszących się zarówno do zagadnień teoretycznych, jak i tych związanych z codzienną praktyką. Na pierwszy plan wysuwają się trudności dotyczące samego procesu diagnozowania, wśród których wymienić można: sposób przeprowadzania diagnozy (standaryzowane kwestionariusze vs rozmowa i obserwacja), jej cel (jednorazowa decyzja czy projektowanie planu pracy), zakres (jeden problem czy pełne rozpoznanie sytuacji życiowej), czy też przedmiot diagnozy (jednostka czy środowisko) (Wysocka 2008, Ostrihanska 2014). Nierzadko kuratorzy przygotowujący diagnozy spotykają się z trudnościami ściśle organizacyjnymi, wynikającymi choćby z nakładu czasu niezbędnego do jej sporządzenia i koniecznością przeprowadzenia wielu diagnoz w krótkim okresie czasu. Z procesem diagnozowania w resocjalizacji wiążą się także problemy natury etycznej. Mogą one dotyczyć przykładowo stosunku do osoby diagnozowanej czy podstawowych czynności diagnostycznych, takich jak sposób pozyskiwania i przetwarzania zebranych informacji i ich weryfikacja w środowisku, co jest istotne, gdyż może skutkować stygmatyzacją osoby (Ostrihanska 2014). Nadto warto mieć w polu widzenia trudności wynikające z coraz szerszego zakresu ochrony danych osobowych i częstej nadinterpretacji przepisów RODO. Coraz trudniejsze jest gromadzenie i weryfikowanie informacji, przy czym nie dotyczy to tylko uczestników postępowania, ale nierzadko także instytucji, które nie przekazują pełnych danych, którymi dysponują.

Wskazane zagadnienia zostaną omówione w niniejszym artykule z uwzględnieniem, co wydaje się szczególnie istotnym, praktycznej perspektywy. Aby móc jednak poddać je analizie, nie sposób pominąć teoretycznych aspektów procesu diagnozowania w pedagogice resocjalizacyjnej.

\section{DIAGNOZA W RESOCJALIZACJI - ZAŁOŻENIA TEORETYCZNE}

Początkowo termin „diagnoza” dotyczył tylko nauk medycznych, gdzie używano go w kontekście rozpoznania rodzaju choroby czy zaburzenia u pacjenta. Następnie poszerzono go o wskazanie możliwości wdrożenia odpowiedniego leczenia. Do nauk społecznych diagnoza została wprowadzona przez Marry Ellen Richmond w 1917 r. - wykorzystała ona reguły diagnozy medycznej i psychiatrycznej do rozpoznania problemów jednostkowych i społecznych (Guziuk-Tkacz 2011).

Diagnozę najczęściej definiuje się w odniesieniu do konkretnej dyscypliny, w której jest ona stosowana (medyczna, psychologiczna) bądź z zaznaczeniem celu, jakiemu 
ma służyć (poznawcza, decyzyjna), co wiąże się z tym, że diagnozę zawsze przeprowadza się z konkretnego powodu (choroba, zaburzenia w funkcjonowaniu szkolnym). Jest ona efektem całego cyklu czynności tworzących jej strukturę, która zawiera opis badanego zjawiska, konkluzję oraz wskazówki będące podstawą zaplanowania działań zaradczych (Guziuk-Tkacz 2011, Skorupka, Auderska, Łempicka 1968).

Szerokie rozumienie terminu „diagnoza”, mające zastosowanie w diagnozach różnego typu, zaproponował Stefan Ziemski, który diagnozę rozumiał jako „rozpoznanie badanego stanu rzeczy przez zaliczenie go do znanego typu albo gatunku, przez przyczynowe i celowościowe wyjaśnienie tego stanu rzeczy, określenie jego formy obecnej oraz przewidywanego dalszego rozwoju" (Ziemski 1973 s. 68). Diagnoza resocjalizacyjna wpisuje się w ogólny model diagnozy zaproponowany przez S. Ziemskiego, ponieważ zawiera wszystkie aspekty pełnej diagnozy, tj. diagnozę identyfikacyjną (klasyfikacyjno-typologiczną), genetyczną, celowościową i prognostyczną (Wysocka 2006).

Podobnie diagnoza jest ujmowana przez Adama Podgóreckiego, który wyróżnia kolejne etapy diagnozy (opis, ocena, konkluzja, tłumaczenie, postulowanie, stawianie hipotez), będące w zasadzie diagnozami cząstkowymi. Podsumowując wyszczególnione elementy, A. Podgórecki rozumie diagnozę jako formułowanie hipotezy, która daje podstawy do zmiany stanu faktycznego, ustalonego w oparciu o wyczerpujący opis oraz ocenę badanej sytuacji (Podgórecki 1962). W pedagogice resocjalizacyjnej diagnoza powinna zawsze wiązać się z podjęciem działań wychowawczych wobec osób przejawiających nieprzystosowanie społeczne, a zatem ma ona służyć nie tylko opisowi zjawiska, jego genezy i dynamiki, ale przede wszystkim odnosić się do praktycznego wymiaru w zakresie możliwości wprowadzania zmian w funkcjonowaniu jednostki. Umożliwia to stworzenie projektu postępowania resocjalizacyjnego, a następnie weryfikację uzyskanych efektów. $\mathrm{W}$ takim rozumieniu diagnoza jest opisem i rozpoznaniem nieprzystosowania społecznego jednostki. Zawiera wyjaśnienie przyczynowe lub teleologiczne oraz ocenę opartą na istniejących standardach pedagogicznych i społecznych, mające na celu zaprojektowanie oddziaływań zapobiegawczych (profilaktycznych) lub korekcyjnych (resocjalizujących) (Pytka 1993).

Z uwagi na praktyczny wymiar diagnozy i złożoność przedmiotu, którego dotyczy, jest ona jedną z najtrudniejszych w obszarze diagnozy pedagogicznej, na co wskazuje Ewa Wysocka (2008). Złożoność zjawiska jakim jest nieprzystosowanie społeczne determinuje przyjęcie interdyscyplinarnego modelu jego oceny i tym samym zaangażowania w proces diagnozy „zespołu refleksyjnych specjalistów" (Wysocka 2016, s. 199). Ponadto istotnym też dla wyjaśnienia zjawiska niedostosowania jest uwzględnienie dwóch wymiarów diagnozy: indywidualnego i środowiskowego (Wysocka 2016). 
Diagnoza, o czym wcześniej wspomniano, może służyć zarówno podjęciu jednorazowej decyzji (np. w przedmiocie umieszczenia małoletniego w placówce opiekuńczo-wychowawczej czy zarządzenia wykonania kary pozbawienia wolności), ale też przygotowaniu całościowo ujętego planu pracy z jednostką w perspektywie kilku lat, jak to ma miejsce w przypadku oddania osoby pod dozór bądź nadzór kuratora. Nadto, na co warto zwrócić uwagę, w kurateli sądowej z reguły ma miejsce sytuacja, w której kurator konstruujący diagnozę jest zazwyczaj osobą wprowadzającą w życie jej zalecenia. Także ta sama osoba dokonuje ich weryfikacji i ewaluacji (Ostrihanska 2014). W takiej sytuacji, stanowiącej bardzo znaczącą część procesu resocjalizacji w warunkach wolnościowych, dochodzi niejako do poszerzenia diagnozy o dodatkowy element jakim jest czas. Diagnoza staje się procesem ciągłym w toku trwania dozoru/nadzoru. Kurator dokonuje weryfikacji diagnozy postawionej w początkowej fazie okresu próby i wynikających z niej oddziaływań oraz ewaluacji osiąganych rezultatów. Prowadzi to w konsekwencji do systematycznego monitoringu procesu resocjalizacyjnego i umożliwia bieżące dostosowanie zamierzeń i działań do dynamicznie zmieniającej się sytuacji. O znaczeniu diagnozy weryfikacyjnej w odniesieniu do konieczności ciągłej kontroli postępów we wprowadzaniu zmian wynikających z diagnozy oraz sprawdzania jej trafności, mówił Lesław Pytka (2000). Wskazywał on, że wykorzystanie poszerzonej procedury diagnostycznej przez kuratora $\mathrm{z}$ uwzględnieniem diagnozy weryfikacyjnej umożliwia modyfikację oddziaływań na każdym etapie procesu resocjalizacji, co sprzyja jego efektywności. Istotnym jest jednak konieczność znacznego zaangażowania się i aktywności ze strony kuratora. Jest to typowy sposób konstruowania diagnozy i prowadzenia pracy z osobą w oparciu o metodę pracy $\mathrm{z}$ indywidualnym przypadkiem, czerpiącą z humanistycznych inspiracji podejścia do jednostki (Kozielecki 2000). Metoda ta jest uznawana za najbardziej wskazaną w warunkach nadzoru i dozoru kuratorskiego, gdyż są w niej realizowane postulaty aktywizowania podopiecznego, jego najbliższego otoczenia i postrzegania go jako indywidualności, która powinna być zaangażowanym uczestnikiem procesu zmian już od początku tworzenia diagnozy. Podopieczny powinien uświadomić sobie własne trudności i potrzebę wprowadzenia zmian w swoim życiu, co sprzyja wzbudzaniu wewnętrznej motywacji (Wojnarska 2011). Wykorzystanie metody indywidualnych przypadków winno być zatem poprzedzone pełną diagnozą w wymiarze indywidualnym i środowiskowym (Paszkiewicz 2006).

Podsumowując dotychczasowe rozważania dotyczące diagnozy resocjalizacyjnej, zwrócić należy uwagę na cel jej formułowania. $Z$ reguły służy ona zaprojektowaniu zmian, a zatem należy uwzględnić w niej rozwój badanych zjawisk, a nie ograniczyć się tylko do poznania aktualnego stanu rzeczy. Ponadto wiedza dotycząca rozwoju i dynamiki obserwowanych zjawisk pozwala poddać je oce- 
nie, czy stanowią one faktyczny przejaw niedostosowania społecznego, czy też są typowe dla etapu rozwojowego, w którym znajduje się jednostka i mają charakter przejściowy (Jaros, Jaros 2014). Pełna diagnoza resocjalizacyjna służąca efektywnemu wprowadzeniu planowanych zmian powinna składać się z kilku diagnoz szczegółowych: nozologicznej (opis sytuacji jednostki i ustalenie problemów), problemowej (ocena problemów będących źródłem zaburzeń), projektującej (określenie zakresu potrzebnych działań naprawczych) i diagnozy weryfikacyjnej (sprawdzenie efektywności działań) (Wysocka 2006). Takie ujęcie diagnozy resocjalizacyjnej jest zgodne z prakseologicznymi założeniami ogólnego schematu diagnozy wychowawczej, opartej na regułach planowego i celowego działania, który może być efektywnie wykorzystany w diagnozie niedostosowania społecznego (Pszczołowski 1993). Pedagog resocjalizacyjny, w celu podjęcia decyzji odnośnie doboru właściwych metod postępowania, powinien rozpoznać rodzaj i dynamikę negatywnych zachowań podopiecznego, następnie określić ich przyczyny i rozpoznać zasoby - tkwiące zarówno w samej jednostce, jak i jej środowisku - które będą sprzyjały powtórnej socjalizacji. Istotnym jest także rozpoznanie czynników ryzyka, co uzupełnia obraz sytuacji o elementy, których stałe oddziaływanie może zniweczyć proces wprowadzania zmian.

Na zakończenie powyższych rozważań warto wspomnieć o ujęciu diagnozy resocjalizacyjnej w kontekście pracy kuratorów sądowych w krajach związanych $\mathrm{z}$ anglosaską tradycją prawa i resocjalizacji, gdyż jest to model zgoła odmienny od polskiego. W piśmiennictwie angielskim w odniesieniu do diagnozy sporządzanej przez kuratorów sądowych powszechnie używa się terminu assessment (ocena, szacowanie), które dodatkowo łączy się z terminem risk (ryzyko). Ma to bezpośredni związek z innym podejściem do procesu diagnozy, jakim jest określanie prawdopodobieństwa powtórnego popełnienia przestępstwa (Barczykowska, Dzierzyńska-Breś, Muskała 2015). Szacowanie ryzyka wywodzi się z przeświadczenia, że w oparciu o ustalenie istnienia i dynamiki określonych czynników można szacować prawdopodobieństwo ponownego popełnienia przestępstwa bądź pogłębiania się niedostosowania społecznego, przejawiającego się w funkcjonowaniu niezgodnym z normami społecznymi. Zatem należy dokładnie określić czynniki ryzyka, do czego służą odpowiednie narzędzia diagnostyczne, a następnie, w oparciu o uzyskane rezultaty (liczbę czynników i ich dynamikę), dokonać kwalifikacji osób diagnozowanych do właściwej kategorii sprawców o niskim, średnim bądź wysokim poziomie ryzyka (Andrews, Bonta, Wormith 2011). Takie podejście do diagnozy w pracy kuratorów dla dorosłych prezentują szczegółowo D.A. Andrews i J. Bonta w modelu teoretycznym R-N-R (Risk-Need-Responsivity), które współcześnie wiąże się z podejściem what works w resocjalizacji. Model swoją nazwę wywodzi od kluczowych w tej koncepcji reguł skutecznego oddzia- 
ływania w oparciu o ryzyko (risk), potrzeby (need) i reaktywność (responsivity). W wyniku badań nad modelem stworzono narzędzia diagnostyczne, które służą do przewidywania poziomu ryzyka powrotności do przestępstwa oraz zawierają elementy pozwalające planować oddziaływania resocjalizacyjne, zgodne $\mathrm{z}$ ustalonym poziomem ryzyka, rzeczywistymi potrzebami kryminogennymi, które są dostosowane do możliwości skazanego (obecnie po wielu modyfikacjach stworzono narzędzie zaliczane do IV generacji, które uwzględnia także potrzebę stworzenia planu: Level of Service/Case Management Inventory - LS/CMI) (Andrews, Bonta, Wormith 2011). Twórcy modelu zwracają uwagę, że celem diagnozy/szacowania jest nie tylko ocena ryzyka ponownego naruszenia, ale też odpowiedź na pytanie co zrobić, aby skutecznie mu przeciwdziałać. Celem stosowania tego modelu jest dostosowanie oddziaływań do konkretnego przypadku, przy czym działania te (w przeciwieństwie do polskiego modelu) są ukierunkowane na profesjonalne formy oddziaływań w postaci programów resocjalizacyjnych, a w mniejszym stopniu na indywidualną pracę z jednostką. Wiąże się to z pragmatycznym paradygmatem oddziaływań profilaktycznych i korekcyjnych opartych na strategii stałej ewaluacji efektów i sprawdzania ich skuteczności (Burnett, Roberts 2004).

Warto nadmienić, że podobne tendencje obserwuje się od kilku lat także w polskiej kurateli dla dorosłych. Kuratorzy na wstępnym etapie diagnozy, w znacznej mierze w oparciu o kryteria wyszczególnione w kodeksie karnym wykonawczym (art. 169b kkw), kwalifikują podopiecznych pozostających pod dozorem do grupy ryzyka powrotu do przestępstwa (A, B lub C). Kwalifikacja do grupy ryzyka winna wiązać się ze zróżnicowaniem oddziaływań wobec dozorowanych w zależności od ustalonej kategorii. Warto jednak wskazać, że polskie rozwiązania będące próbą nawiązania do zachodniej praktyki nie przekładają się faktycznie na prowadzenie pracy resocjalizacyjnej. Zdaniem autorki, jako praktyka, są one niekompletne, sztywne, oderwane od teorii i wynikających z niej zaleceń odnośnie kształtu skutecznych oddziaływań. Dodatkowo kuratorzy nie zostali wyposażeni w żadne narzędzia służące do szacowania ryzyka, a wskazane w przepisach wytyczne często dotyczą statycznych czynników ryzyka i nie uwzględniają faktycznej sytuacji podopiecznego.

\section{DIAGNOZA W PRACY KURATORÓW SĄDOWYCH - PRAKTYCZNE ASPEKTY}

Analizując praktyczne zagadnienia dotyczące konstruowania diagnozy przez kuratorów sądowych, należy zwrócić uwagę na oczekiwania podmiotów, które ją zlecają (sąd, prokuratura, jednostka penitencjarna), aby w oparciu o wskazania 
zawarte w diagnozie podjąć określoną decyzję. W zależności od tego, kto i w jakim celu zleca rozpoznanie sytuacji osoby czy rodziny, której dotyczy postępowanie, będzie wiązało się z podjęciem przez kuratora określonych czynności. Mówiąc inaczej, w zależności od rodzaju decyzji, która ma zostać podjęta, diagnoza będzie koncentrowała się na różnych obszarach. Przykładowo diagnoza przygotowana na zlecenie sądu, który ma podjąć decyzję w przedmiocie ustalenia kontaktów rodzica $\mathrm{z}$ dzieckiem, będzie skoncentrowana na innych aspektach niż diagnoza wykonana na potrzeby rozpatrzenia wniosku w przedmiocie udzielenia skazanemu przerwy w odbywaniu kary pozbawienia wolności. W przypadku postępowań incydentalnych, na potrzeby których kuratorzy przeprowadzają wywiady środowiskowe zawierające diagnozę sytuacji, najczęściej są to czynności jednorazowe i skoncentrowane wokół problematyki wskazanej ściśle przez podmiot zlecający. Inaczej sytuacja przedstawia się, gdy kuratorzy przygotowują diagnozy na potrzeby pracy $\mathrm{z}$ osobą lub rodziną $\mathrm{w}$ ramach orzeczonego nadzoru/dozoru. Wówczas przeprowadzenie diagnozy jest niezbędne, aby zaplanować dalsze etapy pracy wychowawczej lub resocjalizacyjnej. Tego rodzaju czynności diagnostyczne z reguły wymagają znacznego nakładu czasu i pracy, są bardziej wszechstronne i podlegają systematycznej weryfikacji, uzupełnieniu bądź modyfikacji.

Proces konstruowania diagnozy przez kuratorów przebiega według następujących po sobie etapów: zbieranie informacji, opracowanie zebranych informacji oraz przygotowanie wniosków (Ostrihanska 2014). Zbieranie informacji jest istotnym elementem formułowania diagnozy. Źródłami informacji są w głównej mierze dokumenty dotyczące osoby diagnozowanej bądź rodziny. Zaliczyć tu można głównie: akta sądowe, opinie psychologiczne i psychiatryczne, dane dotyczące karalności i dotychczasowych pobytów w zakładzie karnym bądź innych placówkach, opinie ze szkoły, zakładów karnych, dotychczasowa dokumentacja kuratorska (akta poprzednich nadzorów/dozorów oraz wywiady), a także przeprowadzone wywiady w środowisku i poczynione własne obserwacje.

Kuratorzy już w początkowym etapie zbierania informacji muszą odpowiedzieć sobie na pytanie o zakres i ilość gromadzonych informacji - czy należy zmierzać do jak najobszerniejszego rozpoznania sytuacji i zebrania maksymalnej ilości danych? Już ten etap diagnozowania wymaga przyjęcia odpowiedniej strategii działania, do czego dodatkowo skłania ekonomika pracy. W praktyce kuratorskiej jest to obszar stosunkowo często przysparzający trudności. Wynikać to może z faktu, że znacząca część kuratorów nie posiada pedagogicznego wykształcenia, a ich wiedza dotycząca metodyki procesu diagnozowania w znacznej mierze została uzupełniona dzięki samokształceniu, szkoleniom czy doświadczeniom zbieranym w toku praktyki zawodowej. Stąd także szereg dylematów dotyczących poszczególnych etapów pracy nad sformułowaniem trafnej diagnozy. Wracając 
do kwestii zbierania informacji, należy wskazać, że obserwuje się dwa podejścia. $\mathrm{Z}$ jednej strony zebranie bardzo obszernego materiału pozwala na gruntowne rozpoznanie sytuacji osoby diagnozowanej oraz różnych powiązań i zależności między ustalonymi czynnikami. Tym samym może dojść do zwiększenia wartości diagnostycznej zebranego materiału. W drugim podejściu postuluje się bieżącą selekcję informacji i gromadzenie tylko tych wartościowych z punktu widzenia diagnozującego kuratora. W tym przypadku za selekcją danych przemawiają głównie mniejszy nakład czasu potrzebny do obróbki informacji oraz mniejsze ryzyko wyciągnięcia niewłaściwych wniosków z nadmiaru rozproszonych danych (Ostrihanska 2014). Kwestia wyboru odpowiedniego sposobu zbierania danych jest bardzo indywidualna i z pewnością zależy zarówno od uprzedniej znajomości sytuacji osoby, której dotyczy diagnoza (zdarza się często, że kuratorzy pracują kilkukrotnie z tymi samymi osobami bądź członkami ich rodzin), doświadczenia zawodowego (młodsi stażem kuratorzy często zbierają większe ilości danych, aby zminimalizować ryzyko konieczności ich uzupełniania), indywidualnych preferencji kuratora, $\mathrm{w}$ tym także tych związanych $\mathrm{z}$ jego umiejętnościami interpersonalnymi (zaliczyć tu można umiejętność prowadzenia rozmowy, która umożliwia zebranie potrzebnych danych) oraz faktycznej sytuacji osoby dozorowanej (im bardziej skomplikowana sytuacja tym większy zakres zebranego materiału). Warto w tym miejscu zwrócić uwagę na specyfikę relacji jak tworzy się w trakcie spotkania kuratora z podopiecznym. Nierzadko uczestnicy postępowań lub członkowie ich rodzin traktują kuratora jak osobę, od której oczekują pomocy w wielu obszarach (od materialnego po wsparcie psychologiczne). Sprzyja to sytuacjom, w których rozmowa się przedłuża, często odbiegając od głównego wątku, dotykając problemów odnoszących się do całokształtu sytuacji rodziny, co skutkuje, niejako niezamierzonym, pozyskaniem bardzo wielu danych.

W zakresie analizy dokumentacji kuratorzy dysponują bardzo bogatym materiałem zawartym głównie w aktach sądowych. Szczególnie przydatne są opinie psychologiczne i psychiatryczne, gdyż dają one obiektywny obraz sytuacji. Istotnym jest, że zarówno psycholodzy, jak i lekarze psychiatrzy wykorzystują w formułowaniu swoich wniosków standaryzowane narzędzia diagnostyczne w postaci testów, które pozostają poza zasięgiem kuratorów. Zawartość informacyjna dokumentacji pozostającej do dyspozycji kuratorów jest bardzo znacząca i często pozwala, aby $\mathrm{w}$ trakcie prowadzenia wywiadu można było $\mathrm{w}$ większym stopniu skoncentrować się na kwestiach dotyczących sytuacji osobistej osoby diagnozowanej, jej postrzegania i rozumienia sytuacji oraz skupić się na obserwacji, bez konieczności koncentracji na wszystkich szczegółach.

Kolejnym ważnym etapem zbierania informacji, opartym o rozmowę z osobą, której dotyczy diagnoza, ale też jej rodziną i innymi osobami, które mogą wnieść 
wartościowe informacje, jest wywiad środowiskowy. Najczęściej, w praktyce sprowadza się to do zasięgnięcia opinii sąsiedzkiej oraz innych osób mogących dysponować informacjami na temat osoby diagnozowanej np. dzielnicowego, wychowawcy klasy, pracownika socjalnego, terapeuty (Ostrihanska 2014). Kolejne sposoby uzyskiwania informacji w praktyce kuratorskiej to wywiad i rozmowa. $\mathrm{W}$ zasadzie kuratorzy, przygotowując diagnozę, zawsze z nich korzystają, co wynika z metodyki ich pracy i jest dodatkowo regulowane przepisami (art. 11 pkt 2 ustawy o kuratorach sądowych). Ponadto są one źródłem informacji o sytuacji podopiecznego, w tym symptomach nieprzystosowania społecznego oraz zasobach jednostki i jej środowiska, które mogą wspomóc proces resocjalizacji (Wysocka 2015). Przeprowadzenie wywiadu wymaga od kuratora umiejętności warsztatowych dotyczących strategii rozpoczynania i kończenia rozmowy, zadawania pytań jasnych dla rozmówcy, dostosowania słownictwa i umiejętności podtrzymania rozmowy (Gerstmann 1985). Oprócz kompetencji profesjonalnych, ważne są też kompetencje osobiste kuratora, do których można zaliczyć choćby opanowanie, życzliwość, wrażliwość czy dobrą kontrolę emocjonalną oraz umiejętność zdystansowania się i powstrzymywania od oceny (Bielecka 2012). Zebranie wartościowego materiału diagnostycznego w drodze wywiadu i rozmowy zależy zarówno od wiedzy, jak i dojrzałości diagnosty, który sam w toku przeprowadzania wywiadu staje się narzędziem diagnostycznym (Wojnarska 2011).

Ściśle powiązana $\mathrm{z}$ wywiadem i rozmową jest obserwacja, będąca kolejnym sposobem zbierania informacji. Obserwacja towarzyszy każdemu kontaktowi kuratora $\mathrm{z}$ podopiecznym $\mathrm{i}$ jest istotna także $\mathrm{w}$ toku weryfikacji diagnozy $\mathrm{i}$ ewaluacji osiągnięć (Ostrihanska 2014). Należy zwrócić uwagę, że obserwacja nie jest tylko swobodnym przyglądaniem się osobie diagnozowanej i jej otoczeniu, ale polega na planowym i ukierunkowanym postrzeganiu zjawisk i zdarzeń. Opiera się ona głównie na pozawerbalnej sferze kontaktu, będąc specyficznym sposobem zbierania i interpretowania zjawisk w ich naturalnej formie (Łobocki 1982).

Z obserwacją, o czym należy wspomnieć, wiążą się też problemy związane z możliwością nadinterpretacji. Przykładem może być choćby zaobserwowanie w mieszkaniu podopiecznego butelek po alkoholu i na tej podstawie sformułowanie - potencjalnie mylnych - wniosków dotyczących uzależnienia. Dlatego też obserwacja, podobnie jak wywiad, wymagają profesjonalnego przygotowania oraz kompetencji osobistych. Na tym etapie warto wspomnieć o intuicji diagnosty. W każdej działalności człowieka tzw. czynnik ludzki ma znaczenie. Podobnie jest w sytuacji tworzenia diagnozy, kiedy to cechy diagnosty, w tym jego intuicja, są istotne. Intuicja opierająca się na odczuciach „tu i teraz” oraz uruchamianych pozaintencjonalnie skojarzeniach i przemyśleniach pomaga w stawianiu adekwatnych pytań, zwracaniu uwagi na to, co ktoś inny uznałby za nieistotne i poszukiwaniu 
właściwych rozwiązań. Należy jednak pamiętać, że intuicja, choć pomocna i istotna w twórczej fazie tworzenia diagnozy, nie jest narzędziem diagnostycznym (Guziuk-Tkacz 2011). Jest ona czymś na kształt indywidualnej, osobistej kompetencji, polegającej na umiejętności dostrzegania rzeczy „między wierszami”, wrażliwości na pewne niedookreślone aspekty pojawiające się $\mathrm{w}$ trakcie spotkania $\mathrm{z}$ podopiecznym, które mogą ułatwić rozpoznanie stanu faktycznego. Z. Ziemski (1973), odnosząc się do intuicji, sugeruje, że jest ona w pełni racjonalna i wynika $z$ doświadczenia diagnosty, które pozwala na szybką ocenę sytuacji. Przy czym należy pamiętać, że tak postawiona diagnoza, jak każda inna, wymaga sprawdzenia.

Omawiając praktyczne aspekty diagnozowania, koniecznym jest zwrócenie uwagi na to, że proces tworzenia diagnozy implikuje szereg problemów natury etycznej, które mogą wywierać wpływ na jej kształt, ale także mogą skutkować konsekwencjami dotykającymi jednostkę i jej najbliższe otoczenie. Diagnoza tworzona przez kuratorów (często nie będących z wykształcenia pedagogami resocjalizacyjnymi) zazwyczaj dotyczy sytuacji trudnych dla osoby diagnozowanej i jej rodziny, odnosi się do osób, które nierzadko dopuściły się poważnych czynów karalnych. Istotnym jest, aby prywatne przekonania diagnosty nie przekładały się na formułowane opinie. Dlatego też kuratorzy, mając pełną świadomość konsekwencji swoich decyzji, powinni dołożyć wszelkich starań, aby diagnoza była bezstronna i kompletna, a zebrany materiał został zweryfikowany i opracowany tak, by maksymalnie oddawał stan faktyczny.

Innym problemem natury etycznej jest sposób pozyskiwania informacji w środowisku. Opinii środowiskowej należy zasięgać z ostrożnością, aby nie doprowadzić do stygmatyzacji osoby w środowisku jej życia. Wymaga to od kuratora umiejętności pozyskiwania informacji od osób bezpośrednio niezwiązanych z postępowaniem i formułowania na ich podstawie wniosków. W tej sytuacji ma znaczenie także stosunek kuratora sporządzającego diagnozę do osoby diagnozowanej i jej bliskich oraz czasu poświęconego na jej przygotowanie. Oba wskazane czynniki mogą mieć istotny wpływ na konkluzje zawarte w diagnozie (Wysocka 2008). Inną istotną kwestią jest potrzeba podmiotowego traktowania osoby diagnozowanej, niezależnie od czynów jakich się dopuściła oraz niezależnie od jej dotychczasowego funkcjonowania społecznego. Podmiotowe traktowanie polega w głównej mierze na dostrzeganiu w osobie diagnozowanej człowieka godnego szacunku niezależnie od jej wszystkich problemów, nieprzystosowania społecznego, poglądów na otaczająca rzeczywistość i prognozy odnośnie możliwości zmian (Ostrihanska 2014). Podobnie na kształt diagnozy nie powinno mieć wpływu zachowanie osoby diagnozowanej wobec kuratora. Stosunkowo często zdarza się, że osoby, których dotyczy postępowanie diagnostyczne, zachowują się wobec kuratora agresywnie, niechętnie uczestniczą w rozmowie, prezentują roszczeniowy stosunek czy unikają 
kontaktu. Kurator w takich sytuacjach powinien mieć świadomość konieczności oddzielenia swoich osobistych odczuć od zadania, które powinien profesjonalnie wykonać. Innym, ale bardzo znaczącym aspektem, jest czas na sporządzenie diagnozy. Zdarza się, że kuratorzy mają znaczną liczbę obowiązków do wykonania w krótkim okresie czasu, równie absorbujących co diagnoza. Może to sprzyjać powierzchowności opinii bądź skutkować ograniczeniem diagnozy do kilku jej elementów, z pominięciem istotnych, ale czasochłonnych aspektów.

Zgromadzony przez kuratora materiał powinien zostać odpowiednio opracowany i przedstawiony. Istotnym jest sformułowanie konkluzji w przedmiocie prognozy dalszego funkcjonowania (Ostrihanska 2014). Diagnoza sporządzana w toku trwania nadzoru bądź dozoru najczęściej przybiera formę sprawozdania z objęcia i przebiegu, a w przypadku jednorazowego rozstrzygnięcia, sprawozdania $\mathrm{z}$ wywiadu środowiskowego. Kurator, po opracowaniu zebranego materiału i stworzeniu pełnej diagnozy, powinien przedstawić plan dalszej pracy lub, jak to ma miejsce w przypadku wywiadu, zaproponować sądowi określone, dostosowane do sytuacji działanie (Ostrihanska 2014). Są to czynności, które wymagają wiedzy, doświadczenia oraz wrażliwości na drugiego człowieka. Diagnoza przygotowywana przez kuratorów zasadniczo różni się od diagnoz formułowanych w warunkach izolacyjnych (zakłady karne czy młodzieżowe ośrodki wychowawcze) przez osoby specjalizujące się w tej dziedzinie. Kuratorzy często samodzielnie uczą się procesu diagnozowania, opierając się na wiedzy uzyskanej w toku nauki własnej, a rzadziej profesjonalnych szkoleń. Sprzyja to nawarstwianiu się trudności w procesie diagnozowania, pobieżnemu czy też rutynowemu podejściu do analizy uzyskanych informacji oraz błędom.

\section{PODSUMOWANIE}

Proces diagnostyczny jest nieodłącznym elementem praktyki kuratorskiej wymagającym wiedzy oraz samodoskonalenia w toku nabierania doświadczenia zawodowego. Istotne znaczenie odgrywa świadomość czym jest diagnoza, jaki jest jej cel i jakie reguły postępowania należy zastosować, aby była ona przydatna i służyła zaplanowaniu adekwatnych i efektywnych oddziaływań. Kuratorzy sporządzający diagnozę powinni rozumieć, że jej prawidłowe przygotowanie jest warunkiem efektywności resocjalizacji i dlatego jej opracowanie powinno stanowić podstawowy element każdej relacji wychowawczej czy resocjalizacyjnej z podopiecznym już we wstępnej fazie nawiązania współpracy. Warto zatem pogłębiać wiedzę teoretyczną dotyczącą sposobów prawidłowego konstruowania diagnozy, nie poprzestając tylko na wypracowanych w toku praktyki zawodowej 
umiejętnościach. Pozwoli to na doskonalenie warsztatu kuratora jako diagnosty i przyczyni się do podniesienia jakości formułowanych diagnoz (Wojnarska 2011).

Niezależnie od trudności związanych z diagnozowaniem, należy mieć na uwadze fakt, że resocjalizacja, której zasadniczym celem jest powtórne włączenie jednostki do społeczeństwa poprzez spowodowanie zmian $w$ jej zachowaniu polegających na właściwym pełnieniu przez nią ról społecznych i jednoczesnym satysfakcjonującym funkcjonowaniu w wymiarze indywidualnym i ogólnym, wiąże się z koniecznością zaplanowania i podjęcia działań psychokorekcyjnych, co jest możliwe tylko w sytuacji wcześniejszego gruntownego rozpoznania specyfiki występujących trudności i zaburzeń (Stanik 2007, Bałandynowicz 2011). Metodyka pracy kuratorów jasno wskazuje, że podejmowane przez nich działania powinny być zaplanowane i ukierunkowane. Spełnienie tego warunku wymaga szczegółowej diagnozy sytuacji osobistej oraz środowiskowej podopiecznego przy uwzględnieniu czynników ochronnych, tj. zasobów, które sprzyjają powtórnej socjalizacji oraz czynników ryzyka korelujących z pogłębianiem się niedostosowania społecznego (Ostrihanska 2014). Trudności, z którymi borykają się kuratorzy na poszczególnych etapach tworzenia diagnozy, wynikają z wielu przyczyn: począwszy od konieczności uczenia się jej poszczególnych etapów samodzielnie, często metodą prób i błędów, poprzez trudności związane z ograniczeniami czasu na przygotowanie diagnozy, brakiem narzędzi diagnostycznych, aż do kwestii natury etycznej. Wszystkie wskazane problemy ukazują, dlaczego tak ważne jest, aby kuratorzy konstruujący diagnozy posiadali gruntowną wiedzę odnośnie reguł procesu diagnozowania przy użyciu maksymalnie obiektywnych metod oraz posiadali świadomość potrzeby stosowania wysokich standardów etycznych.

Wydaje się zatem zasadnym postulat, szczególnie w sytuacji stawiania kuratorom coraz wyższych wymagań, systematycznego szkolenia ich w przedmiocie etapów konstruowania diagnozy zgodnie z przyjętym modelem teoretycznym i metodologicznym oraz pogłębienia ich świadomości w zakresie możliwości formułowania planów pracy resocjalizacyjnej, opartej na skutecznych i wyraźnie sprecyzowanych metodach adekwatnych do postawionych konkluzji.

\section{LITERATURA}

Andrews D.A., Bonta J., Wormith J.S., 2011, The Risk-Need-Responsivity (RNR) Model: Does Adding the Good Lives Model Contribute to Effective Crime Prevention? "Criminal Justice and Behavior", 38, s, 7. DOI: 10.1177/0093854811406356

Bałandynowicz, A., 2011, Probacja. Resocjalizacja z udziałem społeczeństwa. Warszawa, Wolters Kluwer. 
Barczykowska A., Dzierzyńska-Breś S., Muskała M., 2015, Systemy oddziaływań resocjalizacyjnych w Anglii i Stanów Zjednoczonych Ameryki. Poznań, Wydawnictwo Naukowe UAM.

Bielecka E., 2012, Streetworker a kurator sądowy - szkic porównawczy. „Profilaktyka społeczna i resocjalizacja”, 19, s. 193-216.

Burnett R., Roberts C., 2004, What Works in Probation and Youth Justice. Willan Publishing, Portland-Oregon.

Gerstmann S., 1985, Rozmowa $i$ wywiad w psychologii. Warszawa, PWN.

Guziuk-Tkacz M., 2011, Badania diagnostyczne w pedagogice i psychopedagogice. Warszawa, Wydawnictwo Akademickie „Żak”.

Jaros A., Jaros R., 2014, Czynniki ryzyka i czynniki chroniace związane z zachowaniami problemowymi - przeglad badań przeprowadzonych $w$ Polsce. W: J.E. Kowalska (red.), Zapobieganie wykluczeniu z systemu edukacji dzieci i młodzieży nieprzystosowanej społecznie. Perspektywa pedagogiczna. Łódź, Wydawnictwo Uniwersytetu Łódzkiego, s. 103-115.

Jedynak T., 2014, Ustawa o kuratorach sądowych - „konstytucja” kuratorskiej służby sądowej. W: T. Jedynak, K. Stasiak (red.), Zarys metodyki pracy kuratora sądowego. Warszawa, LexisNexis, wyd. 3.

Kozielecki J., 2000, Koncepcje psychologiczne człowieka. Warszawa, Wydawnictwo Akademickie „Żak”.

Łobocki M.,1982, Metody badań pedagogicznych. Warszawa.

Ostrihanska Z., 2014, Diagnoza w pracy kuratora sądowego. W: T. Jedynak, K. Stasiak (red.), Zarys metodyki pracy kuratora sądowego. Warszawa, LexisNexis, wyd. 3.

Paszkiewicz A., 2006, Wychowanie resocjalizujace $w$ środowisku otwartym - zarys teorii. Białystok, s. 19-33.

Pszczołowski T., 1993, Prakseologia a pedagogika. W: W. Pomykało (red.) Encyklopedia pedagogiczna. Warszawa, Fundacja Innowacja, s. 624-626.

Pytka L., 1993, Diagnostyka w wychowaniu resocjalizujacym. W: W. Pomykało (red.) Encyklopedia pedagogiczna. Warszawa, Fundacja Innowacja, s. 102-105.

Pytka L., 2000, Pedagogika resocjalizacyjna. Warszawa, Wydawnictwo APS.

Podgórecki A., 1962, Charakterystyka nauk praktycznych. Warszawa.

Skorupka S., Auderska H., Łempicka Z. (red.), 1968, Mały Słownik języka polskiego. Warszawa, PWN.

Stanik J.M., 2007, Diagnozowanie niedostosowania społecznego i asocjalności. W: B. Urban, J. M. Stanik (red.) Resocjalizacja. Teoria i praktyka pedagogiczna. Warszawa, Wydawnictwo Naukowe PWN.

Ustawa Kodeks Karny Wykonawczy, Dz. U. Nr 90, poz. 557 ze zm.

Ustawa z dnia 27.07.2001r. o kuratorach sądowych, Dz. U. 2001, Nr 98 poz. 1071. 
Wojnarska A., 2011, Diagnoza resocjalizacyjna - podstawy teoretyczne i problemy praktyczne. W: A. Wojnarska (red.), Diagnostyka resocjalizacyjna. Wybrane zagadnienia. Lublin, Wydawnictwo Uniwersytetu Marii Curie-Skłodowskiej. Wysocka E., 2006, Wybrane problemy diagnozy niedostosowania społecznego - obszary, modele, zasady i sposoby rozpoznawania zjawiska. „Chowanna” 2, s. 7-37.

Wysocka E., 2008, Diagnoza w resocjalizacji, Warszawa, PWN.

Wysocka E., 2015, Diagnoza pozytywna w resocjalizacji. Model teoretyczny i metodologiczny. Katowice, Wydawnictwo Uniwersytetu Śląskiego.

Wysocka E., 2016, Diagnoza pozytywna $w$ działalności pedagoga resocjalizacyjnego założenia teoretyczne i metodologiczne identyfikacji zaburzeń w przystosowaniu. „Lubelski Rocznik Pedagogiczny”, 35, z. 2.

Ziemski S., 1973, Problemy dobrej diagnozy. Warszawa, Sygnały.

\title{
REHABILITATION DIAGNOSIS IN THE PRACTICE OF PROBATION OFFICERS
}

\begin{abstract}
The rehabilitation diagnosis is an inseparable element of curatorial practice. It is closely related to the effectiveness of the undertaken actions. The diagnostic process requires a detailed recognition of the causes, degree and dynamics of social maladjustment as well as the indication of the resources conducive to re-socialization but also the risk factors that may contribute to the destruction of the entire process of change. The consequence of the diagnosis should be determining the possible directions of work with the maladjusted person, the prognosis of their functioning in the future and formulation of a resocialization plan that is adequate to the existing situation. The purpose of this article is to show many difficulties that probation officers face at work making a diagnosis. Formulating a correct diagnosis is a process that requires from the diagnostician both: theoretical knowledge and experience. Comand of the code of conduct and the awareness of the purpose, which the diagnosis serves, is necessary to make decisions and actions towards the charge. This in turn is associated with the effectiveness of the entire rehabilitation process. Therefore, it is justified to postulate the systematic deepening of knowledge in the field of theoretical assumptions and practical skills in diagnosing and using the obtained conclusions in the work with the charge.
\end{abstract}

Keywords: rehabilitation diagnosis, probation officer, social rehabilitation 